\title{
Aesthetic Characteristics of Shanghai Qipao in Chinese Women's Dress Culture
}

\author{
Jing Guo \\ School of Art \\ Shandong Women's University \\ Jinan, China \\ e-mail: guojing811@126.com
}

\begin{abstract}
The art of Qipao, also known as cheongsam, is a typical representative of Oriental beauty. Shanghai is the birthplace of modern Qipao, and the "craftsmanship of Shanghai Qipao" is among the first batch of Shanghai intangible culture heritage. The charm and beauty of Shanghai Qipao have exerted great influence on a whole generation of Chinese women in their choice of clothing. Therefore, the unique aesthetic characteristics of Shanghai Qipao are well worth our profound analysis.
\end{abstract}

Keywords-Shanghai Qipao; aesthetic characteristics; women

\section{INTRODUCTION}

Qipao is regarded as an exotic flower in Chinese women's dress culture for its rich aesthetic characteristics and artistic value. Designed by Han women on the basis of traditional Manchu women clothing, Qipao was a fashion style with Western elements in the early $20^{\text {th }}$ century, which represents a typical combination Eastern and Western cultures. To many westerners, Qipao is a symbolization of the women dress culture in China.

The art of Qipao, also known as cheongsam, is a typical representative of Oriental beauty. Shanghai is the birthplace of modern Qipao, and the "craftsmanship of Shanghai Qipao" is among the first batch of Shanghai intangible culture heritage. The charm and beauty of Shanghai Qipao have exerted great influence on a whole generation of Chinese women in their choice of clothing. Therefore, the unique aesthetic characteristics of Shanghai Qipao are well worth our profound analysis.

\section{THE ORIGIN OF SHANGHAI QIPAO}

Qipao used to refer to the gowns that Manchu people wore. Manchu people are also called Qiren, so that the gowns they wear are called Qipao. Born in the early 20th century, Qipao prevailed in the 1930s and 1940s, and soon swept the whole country from Shanghai after reaching to the peak in 1930s. The expression "Shanghai's style" appeared in the 1920s, invented by some writers in Beijing to criticize some of the literati and writing styles in Shanghai. However, it turns into a commendatory term and gets the meaning of showing off and praising later, when it is used to describe clothing in Shanghai. In respect of dress, "Shanghai's style" is not only a new development of tradition, but it is also a combination of Eastern and Western culture. Shanghai Qipao came into being with the changes of time, and as a collective wisdom of human beings in the history of Chinese women dress culture, it shows unique aesthetic features.

"Shanghai's style", characterized by its integration of Western art, is famous for its originality, flexibility, and commercialization, and Shanghai Qipao is no exception. With

(C) 2014. The authors - Published by Atlantis Press the essence of Eastern and Western dress culture, it took root and flourished in Shanghai, where western life style is highly valued. As a product of the combination of Eastern and Western dress culture, Shanghai Qipao highlights women's curvy figure, which makes Qipao completely gets rid of the old model, becoming a shining pearl in Chinese women dress culture.

\section{ANALYSIS ON THE AESTHETIC CHARACTERISTICS OF SHANGHAI QIPAO}

The beauty of Shanghai Qipao lies in that it is a combination of traditional culture and modern civilization and a product of Chinese and Western cultures. Therefore, its aesthetic characteristics are distinctive in the history of Chinese women dress culture. Its high aesthetic value resides in the style, color, fabric, production process and so on, and we are going to make detailed analysis in these aspects.

\section{A. The Aesthetic Characteristics of Style}

Shanghai Qipao is typical of Qipao in the period of the Republic of China. In most people's minds, the word "Qipao" reminds them of the Shanghai Qipao in the 1930s or 1940s. Traditional Qipao were so deeply affected by feudal ethics that it was impossible for women to show their body curve. As a result, traditional Qipao had been adopting the straight-line shape: the chest, waist, shoulders, buttocks and other parts of the clothes are cut out in the style of flat pattern making. In the early 20th century, the China's political situation went through ups and downs. The 1911 Revolution overthrew the feudal rule of Manchu government, abolished the monarchy, and the Republic of China was established. At the same time, distinctive costume of Manchu women, such as "Dalachi"(hair style) and "Huapengdi"(shoes), disappeared overnight, which created favorable conditions for the birth of a new-style Qipao. During this period, broad sleeved baggy robe-old-fashioned Qipao disappeared. A new type of Qipao came into being in the form of vest, which was worn outside of a short coat, and later designer added sleeves to long vest. On the basis of old-fashioned Qipao, the new type has such features as cumbersome decorations being removed, collar being shortened, sleeves being narrowed, and decorative trim being cut out.

With good observation, Eileen Chang, a famous female writer, is good at describing fashion. She once said, "At the very beginning, Qipao was cold and serious, with Puritan style." In the 1920s, Qipao was still loose and flat with relatively large hem and upside-down “大” shape body. But such parts as shoulder, chest and even the waist, have already showed a trend of tailoring according to people's size. 
1930s and 1940s are the most prosperous period of Qipao, with Shanghai Qipao as a model. At that point, aesthetic features of the style of Qipao became outstanding. A lot of patterns appeared, showing a trend of small collar, low sleeves, and some changes in hem. The collar of Qipao has gone through several changes, from low to high, and from high to none; the sleeves also have gone through some changes, from longer than the wrist to shorter than elbow, and eventually sleeveless. As to the length of Qipao, it can be short, just above women's knees; it can also be long, reaching women's feet and sweeping the ground when they are walking. The slit of Qipao varies from time to time; it can be very low or rather high. In 1934, the slit reached the hips, and the waist was made tighter and tighter. Due to the bold and open style of Qipao women's beautiful legs are exposed perfectly.

In addition to the numerous changes in style, another important feature of Qipao is mingling of Chinese and Western elements. The Opium War broke China's closed-door policy and opened China's door; the 1911 Revolution brought about the influx of Western culture. Qipao learned bust dart and waist dart from western tailoring, and these changes made it more fitted. Apart from inheriting side slits structure, back slits and front opening appeared in Qipao. There were increasing changes in collar, sleeves and hem. Lotus leaf collar, lotus leaf sleeves, slit collar, slit sleeves and other Western-style clothing decoration have been widely adopted by designers.

"Improved Qipao" appeared in the late 1930s. Its cutting method and structural characteristics are more westernized. With the use of bust dart and waist dart, Qipao became more fitted. Meanwhile, the employment of shoulder seam and set-in sleeve made Qipao fit people better in shoulder and armpit part. Mr. Jin Taijun, the successor of Shanghai Hongxiang Tailor Shop, has a strong belief that all the changes in cutting and structure are accomplished in Shanghai. Not having experienced the whole process of change in person, he learned a lot about the changes in style of Shanghai Qipao from an old master craftsman there, when he worked in Hong Xiang in the 1940s.

Up to this period, aesthetic features in style of Qipao have been formed, which serve as the basic structure of style for Qipao after 1930s. Although there are minor changes in length, width, or decoration later, Qipao loved by women around the world derives from Shanghai Qipao in 1930s.

\section{B. The Aesthetic Characteristics of Fabric}

Speaking of aesthetic characteristics of fabric in Shanghai Qipao, we might as well make a comparison between Shanghai Qipao and Beijing Qipao. The fabric of Manchu women's Qipao is mainly thick brocade or jacquard, whose decorations and patterns are tedious. Beijing Qipao pays more attention to the loose style than showing body curve, so that it is particular about decorations. The outstanding aesthetic characteristic of fabric in Beijing Qipao is its various and complicated embroidery or weave pattern, which demonstrates the charm of Qipao completely. By contrast, the fabric of Qipao in the period of the Republic of China is mainly light printed fabrics with relatively simple decorations.
If we compare Beijing Qipao to a lady, a symbol of classicism, Shanghai Qipao is like a modern girl who shows romanticism. In Modern Shanghai, "Chinese-style Westernization" and "Dissemination of West Learning" prompted the westernization of Qipao. The greatest aesthetic feature of Shanghai Qipao is the clever combination of traditional style and Western style, which let it make a bold attempt in the selection of fabrics. In the late 1930s, movie stars became leaders in fashion in Shanghai, and they made great contribution to the prevailing of Qipao. There were lots of fabrics available, such as yarn, crepe, silk, satin, tweed, and cotton, and the fabric of Shanghai Qipao was almost limitless. For a time, "transparent, exposed, slim" is popular, so that hollow fabric and semitranslucent chemical fiber or silk are used by the designers to show a sense of fashion and the charming of women.

Naturally, nowadays there is a wider range of choices in fabrics. In summer, light fabric is the mainstream, such as printed percale, printed poplin, yarn-dyed poplin, colored poplin, a variety of linen, printed sateen, jacquard fabrics, and so on; in spring and autumn, chemical fiber or mixed textiles are used, such as various shot cloth, polyester silk, and a variety of light tweed fabric. The fabrics of Shanghai Qipao are mainly printed or jacquard silk fabrics which are elegant and expensive. As to the patterns on the fabrics of Qipao, floral patterns, animal patterns, stripe patterns, geometric patterns, feather patterns, and integrated patterns are often selected. The aesthetic characteristic of Shanghai Qipao is not simply a manifestation of material form, but a very concrete reflection of the integration of Chinese and Western cultures. Obviously, the aesthetic characteristic of fabrics has a high value in artistic appreciation.

\section{The Aesthetic Characteristic and Value of Craftsmanship}

In addition to its aesthetic features in style and fabric, the exquisite craftsmanship of making Qipao is well worth appreciating. The key aesthetic highlight and feature of Shanghai Qipao in craftsmanship is "made to measure". Each Qipao is tailored according to the customer's figure to develop the strong points and avoid the weak points. An order of one piece of Qipao is acceptable, and the whole dress is completely made by hands in dense and symmetrical stitches, edging naturally. The most noteworthy in the production of Qipao is to pasteup patterns on the basis of the original fabric pattern in order to display the beauty of the cloth completely. In addition, the application of embroidery and Pankou (Chinese Knot button) skills in Shanghai Qipao plays the key role in making it so beautiful that it is actually a piece of art.

The procedures of making Shanghai Qipao have to go through many steps, from cutting to sewing, which are exquisite. Take measuring for example, in order to make sure the size, there are in all 36 different parts of the body to measure. In the process of cutting and sewing, most of the work is done by hands. The process of making and ironing collar will experience four different steps, namely top collar production, under collar production, stitching top collar and under collar, and ironing the collar. The making process of Qipao is more elaborate. Basting tailored fabrics with needle is necessary before sewing the whole dress. 
What particularly worth mentioning is the production of Pankou. Jin Taijun, an old tailor of Hongxiang, once said in an interview with reporters, that common decorations of Qipao include inlaying, binding, inserting, rolling, knotting, embroidering, sticking, and so on, which are very close to the techniques used nowadays. There is a pattern with extraordinarily high technical content, called "Ruyi Tou". "There are about 200 "Ruyi Tou" decorating the best handmade clothes I have ever seen. However, it is a pity that I estimate that no one can make a dress like that now."

\section{Predictions for the Future DeVelopment of Shanghai QIPAO}

Shanghai Qipao is a symbol of art and an interpretation of the life of dress. As a piece of clothing, it has unique vitality; as a work of art, it shows the remarkable wisdom of Chinese women in aesthetic characteristics of dress.

Shanghai Qipao has been listed as Shanghai Intangible Cultural Heritage in 2007, and its future development trend is immeasurable. Wearing Qipao, Maggie Cheung played the role of a mature and charming woman in the 1960s in the film "In the Mood for Love"; Tang Wei in Qipao acted the role of an exquisite and delicate young woman in the 1940s, in the film "Lust, Caution". Both of their excellent performance made women who have a love of beauty crazy about Shanghai Qipao.

Changle Road and Maoming Road in Shanghai are famous street of Qipao. Almost all Shanghai folks know that the two streets are the best place to go if you want to make Qipao, because of their best taste and craft. A lot of women would come here to purchase or make their own wedding dress. There are expensive handcrafted traditional Qipao as well as new-styled Qipao here; there are China Time-honored Brand shops as well as fashionable Qipao shops here.

The wheel of time never stops, so does the development of Shanghai Qipao - a unique dress form. On the basis of inheriting traditional culture, Qipao will pay more attention to its relation to social and economic situation and changes in people's consciousness. In the 2008 Olympic Games, Qipao was worn by hostesses as uniform, showing its splendor to the world once again. In the development of Qipao dress, Shanghai Qipao is a caviar to the general, whose development will not only represent a dress form, but also symbolize the integration and collision of dress culture trend between Shanghai's style and the rest of the world.

As Ye Qingcheng's poem goes, "Shortly after the lights on, she stood in Qipao in the noisy street of the city, sending forth fragrance in gentle breeze. Made of normal fabric, but the colors and patterns of the Qipao are as beautiful as a butterfly; extremely graceful and restrained, the style of the Qipao shows daring sexiness. Quiet yet charming, woman in Qipao looks classical and sexy, as natural and beautiful as Hua Jian Ci (songs among flowers in China)." From her words of praise, it is not difficult to see that Qipao has exuberant vitality and endless charming. China will be more open to the world in the 21 st century, and increasingly higher aesthetical standard for dress is put forward by Chinese women. Their pursuit for beautiful clothes is no longer merely for the simple purpose of "woman makes herself beautiful for her lover", but to look for the dress style and culture taste that suits themselves, and such thought is interpreted by Shanghai Qipao perfectly. Therefore, Shanghai Qipao will have a long and splendid way to go in the future.

\section{REFERENCES}

[1] Huang Qiang, [M] "Chinese Clothing History of Painting." Tianjin. Baihua Literature and Art Publishing House, 2007.8.182-184

[2] Hua Mei, [M] “Chinese Clothing history." Tianjin People's Fine Arts Publishing House, 2000.2.105-120

[3] Yang Jianru, New Changing Clothes--Talk on Aesthetic Characteristics of Cheongsam, Art and Design (theoretical). 2009 (08) 